\title{
Peanut allergy among Mexican adults with allergic respiratory diseases: prevalence and clinical manifestations
}

\section{Alergia al maní en adultos mexicanos con enfermedades respiratorias alérgicas: prevalencia y manifestaciones clínicas}

\author{
Dante Daniel Hernández-Colín, ${ }^{1}$ Eunice Fregoso-Zúñiga, ${ }^{2}$ Jaime Morales-Romero, ${ }^{3}$ Tonantzin Isis Bedolla- \\ Pulido, ${ }^{4}$ Aleyda Carolina Barajas-Serrano, ${ }^{5}$ Angie Bedolla-Pulido, ${ }^{4}$ Martín Bedolla-Barajas ${ }^{1}$
}

\begin{abstract}
Background: Peanut allergy among adults with respiratory diseases has seldom been studied within Mexico.

Objective: To establish the prevalence of peanut allergy among adults that have been diagnosed with either asthma or allergic rhinitis; we will also be describing the symptoms that are associated with peanut allergy.

Methods: We carried out a cross-sectional study through which we analyzed the corresponding data of 257 patients with allergic respiratory diseases, asthma or allergic rhinitis, all participants were 16 years of age or older, and were recruited in a consecutive manner. Peanut allergy was established by testing positive to a peanut skin-prick test; we also conducted a standard interview with each patient.

Results: From our sample of 257 patients, 18 tested positive to peanut sensitization, (7.0\%; 95\% $\mathrm{Cl}=3.9 \%$ to $10.1 \%$ ); among these 18 participants, 7 were considered to be allergic to peanuts (2.7\%; $95 \%$ IC: $0.7 \%$ to $4.7 \%)$. Predominant symptoms were oral, primarily affecting the pharynx and the palate, followed by swelling of the lips. When it came to respiratory discomfort, sneezing and rhinorrhea stood out, and lastly there were cutaneous symptoms. We did not detect any systemic reactions to the peanut.

Conclusion: In our study, peanut allergy among adults with allergic respiratory diseases is not an uncommon occurrence.
\end{abstract}

Keywords: Peanut allergy; Sensitization; Adults

How to cite this article: Hernández-Colín DD, Fregoso-Zúñiga E, Morales-Romero J, Bedolla-Pulido TI, Barajas-Serrano AC, Bedolla-Pulido A, Bedolla-Barajas M. Alergia al maní en adultos mexicanos con enfermedades respiratorias alérgicas: prevalencia y manifestaciones clínicas. Rev Alerg Mex. 2019;66(1):314-321

ORCID

Dante Daniel Hernández-Colín, 0000-0002-2424-9455; Eunice Fregoso-Zúñiga, 0000-0001-8428-1302; Jaime Morales-Romero, 0000-0002-1492-1797; Tonantzin Isis Bedolla-Pulido, 0000-0002-3374-8061; Aleyda Carolina Barajas-Serrano, 0000-0002-6751-0334; Angie Bedolla-Pulido, 0000-0001-5917-0715; Martín Bedolla-Barajas, 0000-0003-4915-1582

${ }^{1}$ Hospital Civil de Guadalajara Dr. Juan I. Menchaca, Servicio de Alergia e Inmunología Clínica, Guadalajara, Jalisco, México ${ }^{2}$ Hospital Civil de Guadalajara Fray Antonio Alcalde, Servicio de Alergia e Inmunología Clínica, Guadalajara, Jalisco, México
${ }^{3}$ Universidad Veracruzana, Instituto de Salud Pública, Xalapa, Veracruz, México 


\section{Resumen}

Antecedentes: La alergia al cacahuate en adultos con enfermedades respiratorias alérgicas pocas veces ha sido estudiada en México.

Objetivo: Establecer la prevalencia de alergia al cacahuate en un grupo de adultos con asma o rinitis alérgica; también se describen los síntomas asociados con la alergia al cacahuate.

Métodos: Se realizó estudio transversal en el que analizaron los datos correspondientes a 257 pacientes con enfermedades respiratorias alérgicas, asma o rinitis alérgica, con edad igual o mayor a 16 años; los pacientes fueron reclutados consecutivamente. La alergia al cacahuate se determinó por una prueba cutánea positiva al cacahuate y a través de una entrevista estandarizada. Se estimaron intervalos de confianza (IC) a $95 \%$ para proporciones.

Resultados: De los pacientes incluidos, 18 estuvieron sensibilizados al cacahuate (7.0 \%, IC 95 \% = 4.4-10.9), siete de ellos fueron considerados alérgicos al cacahuate, para una prevalencia de $2.7 \%$ (IC 95\%: 1.2\% - 5.6\%). En los pacientes con alergia al cacahuate, los síntomas predominantes fueron los orales, principalmente el prurito en la faringe y en el paladar, seguidos de edema de los labios; entre las molestias respiratorias sobresalieron los estornudos y la rinorrea y, al final, los síntomas cutáneos. No se documentaron reacciones sistémicas al cacahuate.

Conclusión: En nuestro estudio, la alergia al cacahuate en adultos con enfermedades respiratorias alérgicas no fue infrecuente.

Palabras clave: Alergia al cacahuate; Sensibilización; Adultos

${ }^{4}$ Universidad de Guadalajara, Centro Universitario en Ciencias de la Salud, Guadalajara, Jalisco, México ${ }^{5}$ Colegio Mexicano de Inmunología Clínica y Alergia, Guadalajara, Jalisco, México
Correspondence: Martín Bedolla Barajas. drmbedbar@gmail.com

Received: 2019-04-23

Accepted: 2019-07-21

DOI: $10.29262 /$ ram.v66i3.619

\section{Background}

Globally, the prevalence of allergies to foods such as the peanut has seen a substantial rise, to the point of becoming a public health issue. ${ }^{1}$ Peanut allergy is amongst the main causes of deaths associated with anaphylaxis induced by foods; $;{ }^{2,3}$ however, there are countries where this does not appear to be a major problem.

Most patients with peanut allergy begin to manifest symptoms at an early age, and it is likely that these will persist throughout the individual's lifetime. ${ }^{4}$

In Mexico, peanut sensitization appears to be less frequent than in the United States and Europe, where it represents about $80 \%$ of food allergies. ${ }^{5}$ In Latin America, a region with various emerging economies, foods such as peanuts constitute an alternative protein source, however, little is known about the peanut allergy frequency in the region. ${ }^{6}$ Moreover, the vast cultural diversity, food avail- ability, tropical and subtropical climates, as well as peanut intake tendencies, all lead to differing dietary and food preparation habits that may not be found in developed economies, all of which cause variability among peanut allergy development. ${ }^{7,8}$

In Mexico, the issue regarding peanut allergy among adults has seldom been analyzed; there is a generally held notion that food allergy is more of a problem within the pediatric population. Given these circumstances, the objectives of our study were: Firstly, to determine the prevalence of peanut allergy among a sample group with allergic respiratory diseases, and secondly, to describe the symptoms that are most frequently triggered by peanut ingestion among our sample group of patients.

\section{Methods}

In this cross-sectional study, we included patients that reside within the metropolitan region of Guada- 
lajara, Mexico, that have allergic respiratory diseases, either allergic asthma or allergic rhinitis, aged 16 years or older. These patients received allergy-related medical attention for the first time in a teaching hospital. The subjects were recruited consecutively from April 2017 to April 2018. We did not include patients with dermographism, nor did we incorporate pregnant women, or those who were unable to suspend their antihistamine intake.

Conventionally, when a patient shows allergy sensitization to at least one of the tested aeroallergens, we proceed to apply food allergy skin-prick tests. In our study, if a peanut skin-prick test came up positive, we also interviewed the patient regarding the symptoms that he or she manifested after ingesting this particular food.

Peanut allergy was determined when there was a positive peanut allergen skin-prick test and the presence of symptoms within 2 hours of having ingested peanuts; these symptoms were identified through a standard interview conducted by two trained allergists.

Skin-prick tests were carried out by using the puncturing technique with a non-standardized commercial peanut extract (1:20 p/v; Allergomex, Ciudad de Mexico, Mexico); we used glycerin and histamine as negative and positive controls, respectively. Usually, patients are instructed to avoid medication that can interfere with skin-prick test results for at least one week prior to the test, especially antihistamines. Along with a peanut allergen, we also tested for aeroallergens with pollen from weeds (careless weed, ragweed, mugwort, lambs' quarters, sunflower, castor bean, Russian thistle, dandelion), grasses (Bermuda grass, Johnson grass, ryegrass, timothy) and trees (sweet acacia, alders, casuarina, cypress, eucalyptus tree, ash, juniper, pine, poplar, mesquite, oak, American pepper), as well as indoor allergens (Dermatophagoides farinae, Dermatophagoides pteronyssinus, a mix of Blattella germanica and Periplaneta americana, cat and dog fur), lastly, a mix of feathers were also tested (Allergomex, Ciudad de Mexico, Mexico). A drop of every allergen was situated over each patient's anterior forearm, subsequently; we used a standard lancet for the puncturing (Hollister-Stier ${ }^{\circledR}$ ). Every patient had to wait 15 minutes before the tests could be interpreted. Based on international guidelines, a test was considered positive when the size of the wheal was $\geq 3 \mathrm{~mm}$ when compared to the negative control. ${ }^{9}$
The prevalence of peanut allergy was determined as the result of the division of the number of patients that manifested symptoms after ingesting peanuts by the entire study sample; moreover, $95 \%$ confidence intervals $(95 \% \mathrm{CI})$ for proportions were calculated to estimate population prevalence of peanut sensitization and peanut allergy. The processing and data analyses were done with IBM SPSS ${ }^{\circledR}$ Statistics 20 (IBM Corp., Armonk, NY, USA). The license was acquired by the institution that approved this study.

This investigation was approved by the Hospital's Ethics Committee (Ethics Committee number 00166). Each patient signed a written consent form in order to be included in our study.

\section{Results}

We analyzed the data of 257 adults with allergic respiratory diseases; exclusively with allergic rhinitis were 158 , asthma without allergic rhinitis were 28 and asthma with allergic rhinitis were 72 ; in which the frequency for peanut sensitization $(\mathrm{n}=18)$ was $7.0 \%(95 \% \mathrm{CI}=3.9-10.1)$, the mean age for this group was $33.7 \pm 14.2$ years; there was a greater prevalence in women than in men with a 2:1 ratio (table 1). In the peanut sensitization group, a little over $60 \%$ of the patients have allergic rhinitis. In addition to peanut sensitization, almost $80 \%$ of the patients were also sensitized to indoor dust mites or one of the tree pollens.

The prevalence of individuals with peanut allergy $(7 / 257)$ was $2.7 \%(95 \% \mathrm{CI}=0.7-4.7)$. In this case, the mean age was $27.4 \pm 11.6$ years; in total, there were six women and one man out of all the cases. Among these patients, gastro-intestinal symptoms and those around the oral area were the most predominant, such as: an itchy throat and palate, followed by swelling of the lips; among the respiratory symptoms, the most common were sneezing and rhinorrhea; cutaneous symptoms were the least prevalent (table 2).

In table 3 there is a detailed list of clinical characteristics for patients with peanut allergy. All seven patients had allergic rhinitis, one of which had asthma; all were sensitized to tree pollens. The median wheal size of peanut skin prick test was $4 \mathrm{~mm}$.

\section{Discussion}

One of our most notable findings was a peanut allergy prevalence of $2.7 \%$ among adults with respiratory 
diseases; additionally, itchiness of throat and palatine stood out, among digestive symptoms associated with this problem.

Although the growing peanut allergy prevalence is well documented, the cultural differences between developed and emerging countries might be factors that contribute to the variation of this specific allergy. Up until a few years ago in The United Kingdom, parents had been advised not to introduce peanuts into the diet of their children until they were 3 years of age, interestingly, the Jewish population did not apply this restriction, a circumstance which led to a reduced peanut allergy prevalence. ${ }^{10,11}$ Studies in France regarding the growing prevalence of this sensitization have found that ingesting peanuts while pregnant, breastfeeding, and at the age during which a complimentary diet is introduced to nursing infants were the cause of increased peanut allergy prevalence. ${ }^{12}$

Within the Asian continent, peanut allergy prevalence is not very common, in Korea, Singapore, and the Philippines, its frequency ranges from 0.4 to $1.1 \%$ among children; ${ }^{13}$ conversely, in countries such as The United Kingdom, Canada, The United States of America, and Australia the prevalence is almost twice as high; in fact, western countries have doubled their peanut allergy prevalence in the last two decades. ${ }^{14}$

When trying to evaluate the possible causes that would lead to a difference in peanut allergy prevalence between Asian and Western countries, it has been suggested that early exposure to cooked or boiled peanut in baby food, may help develop a tolerance to it, ${ }^{13}$ furthermore, it has been noted that ingesting roasted peanuts increases allergenicity. ${ }^{15}$ Other aspects that play a role in this matter are genetic variability and microbial exposure in migrant populations, as these tend to modulate intestinal immunity and build a tolerance. ${ }^{16}$ Interestingly, in countries where the peanut allergy frequency is higher, mutations have been found in the gene that codes filaggrin, which causes a higher environmental exposure to the peanut protein as a result of the deficient cutaneous barrier, thus, it increases the likelihood of developing allergy to this food. ${ }^{17}$ On the other hand, in Singapore the study showed that regardless of an individual's ethnic background, patients born in Asia were at a lower risk for developing a peanut allergy than those born in Western countries. ${ }^{17}$ The

\begin{tabular}{|c|c|c|}
\hline \multirow[t]{2}{*}{ Age in years ( mean $\pm S D$ ) } & \multicolumn{2}{|c|}{$33.7 \pm 14.2$} \\
\hline & $\mathrm{n}$ & $\%$ \\
\hline \multicolumn{3}{|l|}{ Sex } \\
\hline Female & 12 & 66.7 \\
\hline Male & 6 & 33.3 \\
\hline \multicolumn{3}{|l|}{ Allergic disease } \\
\hline Allergic rhinitis & 11 & 61.1 \\
\hline Asthma + allergic rhinitis & 4 & 22.2 \\
\hline Asthma & 3 & 16.7 \\
\hline \multicolumn{3}{|l|}{ Allergic sensitization } \\
\hline House dust mite & 14 & 77.8 \\
\hline Tree pollens & 14 & 77.8 \\
\hline Weed pollens & 11 & 61.1 \\
\hline Grass pollens & 11 & 61.1 \\
\hline Cockroach (mix) & 10 & 55.6 \\
\hline Fungi & 7 & 38.9 \\
\hline Cat & 6 & 33.5 \\
\hline Dog & 4 & 22.2 \\
\hline Feathers (mix) & 2 & 11.1 \\
\hline $\mathrm{SD}=$ standard deviation. & & \\
\hline
\end{tabular}

data from Asia and Africa have shown that peanut allergy is less prevalent in countries with emerging economies, in contrast to developed nations, where there is a higher frequency. ${ }^{18,19}$ These studies have also reported varying genetics within the population, concluding that peanut allergy may be linked to a microbial exposure and the environment. ${ }^{20,21}$

Previous studies in Mexico were carried out among children with allergic diseases, where it was observed that peanut allergy prevalence was at $3.3 \% .^{5}$ In our country, there are limited studies that have looked into the risk factors associated with peanut allergy; primarily, exposure and sensitization to pollens, oral allergy syndrome, job occupations, and contact with food proteins through direct skin contact, soaps or body lotions. ${ }^{22}$ In our analysis, sensitization to tree pollens, especially the oak, mesquite and alder pollens, was present in almost $80 \%$ of the patients. It seems that peanut allergy prevalence is likely triggered by a reactive pollen mixture, especially mixtures found in grasses ${ }^{23,24}$ Recently, it 


\begin{tabular}{|c|c|c|}
\hline Symptoms & $\mathrm{n}$ & $\%$ \\
\hline Intestinal & 7 & 100.0 \\
\hline Oral & 6 & 85.7 \\
\hline Itchy throat & 5 & 72.3 \\
\hline Itchy palate & 3 & 42.8 \\
\hline Swollen lips & 2 & 28.6 \\
\hline Itchy lips & 2 & 28.6 \\
\hline Itchy tongue & 1 & 14.3 \\
\hline Sialorrhea & 1 & 14.3 \\
\hline Lower Intestinal & 1 & 14.3 \\
\hline Abdominal pain & 1 & 14.3 \\
\hline Abdominal distention & 1 & 14.3 \\
\hline Respiratory & 2 & 28.6 \\
\hline Sneezing & 1 & 14.3 \\
\hline Rhinorrhea & 1 & 14.3 \\
\hline Cutaneous & 1 & 14.3 \\
\hline Itchy skin & 1 & 14.3 \\
\hline Hives & 1 & 14.3 \\
\hline Swollen body parts & 1 & 14.3 \\
\hline
\end{tabular}

was noted that adolescents and adults with peanut allergy also had a $50 \%$ rate of birch sensitization. ${ }^{25}$ It would seem that the similarity found in the peanut proteins and the pollen allergens that come from the oak, mesquite and alder trees, which have caused sensitization in our patients, belong to the profilines family, ${ }^{24}$ and these are capable of triggering a cross-reactivity and cause peanut allergy.

Notably, we also found a predominance of oral symptoms in patients with asthma and allergic rhinitis; these are similar to the results in another Mexican investigation, where the most frequent allergic disease related to oral allergy syndrome was allergic rhinitis. However, in said study, the foods with the greatest relationship to oral allergy syndrome were fruits. ${ }^{26}$ In our study, we found no predominance for systemic peanut allergy symptoms; in fact, in North America the peanut is the food that causes the greatest number of anaphylactic fatalities, both in adolescents and in young adults. ${ }^{27}$ Other studies focused on the clinical evolution and the severity of peanut allergy have shown that those proteins found in peanuts, that have a greater thermal stability and greater resistance to the gastric proteolytic enzymes, also have a greater allergenic capacity, such is the case for Ara h 2 and Ara h 9. ${ }^{28}$ When we compare studies regarding clinical variability of peanut allergy and its association with different sensitizations to food proteins, it has been proven that North American patients with peanut allergy primarily have an Ara h 2 sensitization. The opposite, that is, a Ara h 5 and Ara h 8 sensitization occurs in Northern Europe (Sweden, Denmark, Germany). In contrast, Mediterranean patients in countries such as Spain and India have peanut allergy with Ara h 9 sensitization. It has been noted that patients with peanut allergy that also have oral allergy syndrome, are sensitized to Ara $h$ 5 and Ara h 8. ${ }^{29}$ Given that in our sample of patients with peanut allergy tended to manifest oral symptoms, we can infer that these were Ara h 5 or Ara h 8 sensitizations. We can also discard that their allergic problem began throughout the later stages of life because there were no documented systemic reactions.

It is known that only $20 \%$ of peanut allergy cases will be resolved at school age, especially those that show mild to moderate reactions and do not manifest other allergic reactions. ${ }^{28}$ The primary treatment for patients with peanut allergy is to avoid exposure to it, although we know that it can be difficult since the peanut can be hidden in many food products, thus, there is a high risk for accidental exposure to those that suffer from the allergy. ${ }^{29}$ Therefore, those patients with persistent oral symptoms that are constantly exposed might develop systemic symptoms in the future..$^{30-32}$

Interventions with impact on public health to prevent peanut allergy, such as early diagnosis, could reduce direct costs for medical attention and indirect costs for improving the quality of life..$^{33,34}$

Due to the design of our study all variables were measured simultaneously; as a result, we were unable to effectively determine which patients developed anaphylactic reactions; although based on our interviews, none of them did. An additional limitation to our results was that we could not do oral food challenge tests, in order to confirm the allergic diagnosis. Furthermore, we did not estimate the average peanut consumption intake prior to the onset of symptoms associated with peanut ingestion, as these patients did not have medical records at our hospital.

Selection bias should always be considered when using a diagnostic test. For example, if we had used a 


\begin{tabular}{|c|c|c|c|c|c|c|c|}
\hline Cases & 1 & 2 & 3 & 4 & 5 & 6 & 7 \\
\hline Sex & $\mathrm{F}$ & $M$ & $\mathrm{~F}$ & $\mathrm{~F}$ & $\mathrm{~F}$ & $\mathrm{~F}$ & $\mathrm{~F}$ \\
\hline Age in years & 21 & 26 & 25 & 20 & 30 & 52 & 18 \\
\hline Asthma & - & - & - & - & - & - & - \\
\hline Allergic rhinitis & - & + & + & + & + & + & + \\
\hline Asthma + allergic rhinitis & + & - & - & - & - & - & - \\
\hline \multicolumn{8}{|l|}{ Symptoms } \\
\hline Respiratory & + & + & - & - & - & - & - \\
\hline Cutaneous & - & - & - & - & - & - & + \\
\hline Lower intestinal & - & - & - & - & - & + & + \\
\hline Oral & + & + & + & + & + & - & - \\
\hline \multicolumn{8}{|l|}{ Skin-prick test } \\
\hline House dust mites & + & + & + & + & - & + & + \\
\hline Cockroach & + & - & + & + & + & - & + \\
\hline Cat & + & - & + & - & + & - & - \\
\hline Dog & - & - & + & - & - & - & - \\
\hline Trees & + & + & + & + & + & + & + \\
\hline Weed & - & - & + & + & + & - & - \\
\hline Grass & - & + & + & - & + & - & + \\
\hline Fungi & - & - & - & - & + & + & + \\
\hline Peanut, wheal size $(\mathrm{mm})$ & 3 & 5 & 4 & 3 & 4 & 3 & 4 \\
\hline $\mathrm{F}=$ female, $\mathrm{M}=$ male & & & & & & & \\
\hline
\end{tabular}

questionnaire about allergy symptoms after ingestion of peanuts, it is possible that patients could overestimate or underestimate their symptoms, so the prevalence would be erroneously calculated. In contrast, the skin prick test used in this study has been shown to be a test with high discrimination capacity, with an area under the curve of over $90 \%$ according to the receiver operating curves. ${ }^{35}$ In clinical practice this test has proved very useful since a size of the wheal greater than $1 \mathrm{~mm}$ has a sensitivity of $100 \%$, but a size of the wheal greater than $5 \mathrm{~mm}$ has a specificity of $100 \%$.

In closing, there are a considerable number of patients with allergic asthma or rhinitis that are also sensitized to the peanut; among them, almost $40 \%$ manifested symptoms, primarily oral symptoms that were linked to peanut ingestion.

\section{References}

1. Tham EH, Leung DYM. how different parts of the world provide new insights into food allergy. Allergy Asthma Immunol Res. 2018;10(4):290-299. DOI: 10.4168/aair.2018.10.4.290

2. Samady W, Trainor J, Smith B, Gupta R. Food-induced Anaphylaxis in Infants and Children. Ann Allergy Asthma Immunol. 2018;121(3):360-365. DOI: 10.1016/j.anai.2018.05.025

3. Katz Y. Food allergy epidemic: can we reverse the trend? Isr Med Assoc J. 2012;14(1):5-6. Available in: https://www.ima.org.il/FilesUpload/IMAJ/0/38/19313.pdf

4. Togias A, Cooper SF, Acebal ML, Assa'ad A, Baker JR, Beck LA, et al. Addendum guidelines for the prevention of peanut allergy in the United States: report of the National Institute of Allergy and Infectious 
Diseases sponsored expert panel. World Allergy Organ J. 2017;10(1):1. DOI: 10.1186/s40413-0160137-9

5. Bedolla-Barajas M, Valdez-López F, Alcalá-Padilla M, Bedolla-Pulido TI, Rivera-Mejia V. MoralesRomero J. Prevalence and factors associated to peanut allergy in Mexican school children. Allergol Immunopathol (Madr). 2017;45(1):69-76. DOI: 10.1016/j.aller.2016.04.013

6. Sánchez J, Sánchez A. Epidemiology of food allergy in Latin America. Allergol Immunopathol (Madr). 2015;43(2):185-195. DOI: 10.1016/j.aller.2013.07.001

7. Walker MT, Green JE, Ferrie RP, Queener AM, Kaplan MH, Cook-Mills JM. Mechanism for initiation of food allergy: dependence on skin barrier mutations and environmental allergen costimulation. J Allergy Clin Immunol. 2018;141(5):1711-1725. DOI: 10.1016/j.jaci.2018.02.003

8. Foong $\mathrm{RX}$, Brough $\mathrm{H}$. The role of environmental exposure to peanut in the development of clinical allergy to peanut. Clin Exp Allergy. 2017;47(10):1232-1238. DOI: 10.1111/cea.12992

9. Van Kampen V, De Blay F, Folletti I, et al. EAACI position paper: skin prick testing in the diagnosis of occupational type I allergies. Allergy. 2013;68(5):580-584. DOI: 10.1111/all.12120

10. Peters RL, Koplin JJ, Gurrin LC, Dharmage SC, Wake M, Ponsonby AL, et al. The prevalence of food allergy and other allergic diseases in early childhood in a population-based study: Health Nuts age 4 year follow up. J Allergy Clin Immunol. 2017;140(1):145-153. DOI: 10.1016/j.jaci.2017.02.019

11. Wang Y, Allen KJ, Suaini NHA, Peters RL, Ponsonby AL, Koplin JJ. Asian children living in Australia have a different profile of allergy and anaphylaxis than Australian-born children: a State-wide survey. Clin Exp Allergy. 2018;48(10):1317-1324. DOI: 10.1111/cea.13235

12. Husain Z, Schwartz RA. Peanut allergy: an increasingly common life-threatening disorder. J Am Acad Dermatol. 2012;66(1):136-143. DOI: 10.1016/j.jaad.2011.02.031

13. Lee AJ, Thalayasingam M, Lee BW. Food allergy in Asia: how does it compare? Asia Pac Allergy. 2013;3(1):3-14. DOI: 10.5415/apallergy.2013.3.1.3

14. Dunlop JH, Keet CA. Epidemiology of food allergy. Immunol Allergy Clin North Am. 2018;38(1):13-25. DOI: 10.1016/j.iac.2017.09.002

15. Cabanillas B, Novak N. Effects of daily food processing on allergenicity. Crit Rev Food Sci Nutr. 2019;59(1):31-42. DOI: 10.1080/10408398.2017.1356264

16. Fleischer DM, Sicherer S, Greenhawt M, Campbell D, Chan E, Muraro A, et al. Consensus communication on early peanut introduction and prevention of peanut allergy in high-risk infants. Ann Allergy Asthma Immunol. 2015;115(2):87-90. DOI: 10.1016/j.anai.2015.06.001

17. Asai Y, Eslami A, Van Ginkel CD, Akhabir L, Wan M, Ellis G, et al. Genome-wide association study and meta-analysis in multiple populations identifies new loci for peanut allergy and establishes C11orf30/ EMSY as a genetic risk factor for food allergy. J Allergy Clin Immunol. 2018;141(3):991-1001. DOI: 10.1016/j.jaci.2017.09.015

18. Platts-Mills TA. The allergy epidemics: 1870-2010. J Allergy Clin Immunol. 2015;136(1):3-13. DOI: 10.1016/j.jaci.2015.03.048

19. Gray CL, Levin ME, Du Toit G. Which test is best for diagnosing peanut allergy in South African children with atopic dermatitis? S Afr Med J. 2016;106(2):214-220. DOI: 10.7196/SAMJ.2016.v106i2.10125

20. Tham EH, Shek LP, Van Bever HP, Vichyanond P, Ebisawa M, Wong GW, et al. Early introduction of allergenic foods for the prevention of food allergy from an Asian perspective-an Asia Pacific Association of Pediatric Allergy, Respirology \& Immunology (APAPARI) consensus statement. Pediatr Allergy Immunol. 2018;29(1):18-27. DOI: 10.1111/pai.12820

21. Strachan DP. Family size, infection and atopy: the first decade of the "hygiene hypothesis". Thorax. 2000;55(Suppl 1):S2-S10. DOI: 10.1136/thorax.55.suppl_1.s2

22. Iweala OI, Choudhary SK, Commins SP. Food allergy. Curr Gastroenterol Rep. 2018;20(5):17. DOI: 10.1007/s11894-018-0624-y

23. Kazatsky AM, Wood RA. Classification of Food Allergens and Cross-Reactivity. Curr Allergy Asthma Rep. 2016; 16:22. 
24. Park KH, Son YW, Lee SC, Jeong K, Sim da DW, Park HJ, et al. Clinical significance of component allergens in fagales pollen sensitized peanut allergy in Korea. Allergy Asthma Immunol Res. 2016;8(6):505-511. DOI: 10.4168/aair.2016.8.6.505

25. Valcour A, Jones JE, Lidholm J, Borres MP, Hamilton RG. Sensitization profiles to peanut allergens across the United States. Ann Allergy Asthma Immunol. 2017;119(3):262-266. DOI: 10.1016/j.anai.2017.06.021

26. Bedolla-Barajas M, Morales-Romero J, Ortiz-Miramontes LR, Jáuregui-Franco RO. Frequency and clinical features of the oral allergy syndrome in Mexican Adults with nasal pollinosis. Rev Alerg Mex. 2013;60(1):17-25.

27. Bartnikas LM, Huffajer MF, Sheehan WJ, Kanchongkittiphon W, Pretty CR, Leibowitz R, et al. Impact of school peanut free policies on epinephrine administration. J Allergy Clin Immunol. 2017;140(2):465-473. DOI: 10.1016/j.jaci.2017.01.040

28. Moreno MA. Guidelines to help prevent peanut allergy. JAMA Pediatr. 2017;171(1):100. DOI: 10.1001/ jamapediatrics.2016.3085

29. Leickly FE, Kloepfer KM, Slaven JE, Vitalpur G. Peanut allergy: an epidemiologic analysis of a large database. J Pediatr. 2018;192:223-228. DOI: 10.1016/j.jpeds.2017.09.026

30. Bedolla-Barajas M, Bedolla-Pulido TR, Camacho-Peña AS, González-García E, Morales-Romero J. Food hypersensitivity in Mexican adults at 18 to 50 years of age: a questionnaire survey. Allergy Asthma Immunol Res. 2014;6(6):511-516. DOI: 10.4168/aair.2014.6.6.511

31. Thong BY, Arulanandam S, Tan SC, Tan TC, Chan GY, Tan JW, et al. Shellfish/crustacean oral allergy syndrome among national service pre-enlistees in Singapore. Asia Pac Allergy. 2018;8(2):e18. DOI: 10.5415/apallergy.2018.8.e18

32. Sampson HA. Anaphylaxis and emergency treatment. Pediatrics. 2003;111(6 Pt 3):1601-1608. Available in: https://pediatrics.aappublications.org/content/111/Supplement_3/1601.long

33. Wassenberg J, Cochard MM, Dunngalvin A, Ballabeni P, Flokstra-De Blok BM, Newman CJ, et al. Parent perceived quality of life is age-dependent in children with food allergy. Pediatr Allergy Immunol. 2012;23(5):412-419. DOI: 10.1111/j.1399-3038.2012.01310.x

34. Patel DR, Upton JEM, Wang J, Harada L, Guffey D, Minard CG, et al. Quality of life for parents of children with food allergy in peanut-restricted versus peanut-free schools in the United States and Canada. J Allergy Clin Immunol Pract. 2018;6(2):671-673. DOI: 10.1016/j.jaip.2017.08.013

35. Simms E, Foster G, Arias K, Larché M, Freitag T, Walker T, et al. Prediction of clinical peanut allergy status among children in Hamilton, Ontario using chart review data collected during 2012-2015. Allergy Asthma Clin Immunol. 2017;13:10. DOI: 10.1186/s13223-017-0179-8 